\title{
Role of Zinc Oxide Nanoparticles in Mitigation of Drought and Salinity
}

\author{
Pooja $^{1}$, Renu Munjal ${ }^{1 *}$, Jayeeta Bhaumik ${ }^{2}$ and Ravneet Kaur ${ }^{2}$ \\ ${ }^{1}$ Department of Botany and Plant Physiology, CCS Haryana Agricultural University, India \\ ${ }^{2}$ Department of Nanomaterials and Application Technology, DBT-CIAB (GOI), Mohali, India \\ *Corresponding author
}

Keywords

Zinc Oxide

Nanoparticles,

Drought and

Salinity

Article Info

Accepted:

07 October 2020

Available Online:

10 November 2020
A B S T R A C T

Currently agriculture is facing challenges like increase in global population, hunger and extreme poverty due to which rate of agricultural yield increase has declined. The main reason behind declined agricultural yield is abiotic stresses suffered by sessile plants. Salinity and drought are two major abiotic stresses which result in yield losses for example it is estimated that drought and salinity may cause $50 \%$ loss in crop production. In the fast moving world, a new technique of nanotechnology is adopted to overcome this problem. Zinc oxide nanoparticles are the particles which have dimension between $0-100 \mathrm{~nm}$. Zinc is one of the most important micronutrient used in different physiological processes like hormone biosynthesis, synthesis of chlorophyll and cofactor of enzyme like carbonic anhydrous, superoxide dismutase etc. Zinc oxide nanoparticles on the other hand are are less toxic, comparatively inexpensive and biocompatible nanoparticles as compared to other metal oxide nanoparticles because zinc does not interact with the majority of pharmaceutically active molecules. $\mathrm{ZnO}$ has been "generally recognized as safe (GRAS)" material by the Food and Drug Administration and is utilized as a food additive. Zinc oxide nanoparticles have potential for mitigating abiotic stress like salinity and drought as they are involved in synthesis of auxin which in turn activate cell division and enlargement, maintain integrality of biomembranes, accumulation of phospholipids, improvement in protein synthesis, scavenging free oxygen radicals, nutrient translocation from the aged cells to newborn cells, decreasing the uptake of excess of $\mathrm{Na}^{+}$and $\mathrm{Cl}^{-}$and $\mathrm{Zn}$ also play an important role in opening and closing the stomatal pore and controlling the process of photosynthesis and alters the stomatal conductance and transpiration. In this review, use of zinc oxide nanoparticles to mitigate the effects of abiotic stresses in order to increase the yield potential of crops are discussed

\section{Introduction}

\section{Zinc an essential nutrient}

The process of diffusion enables the Zinc micronutrient to reach the plant roots but dry soil and less organic matter impair this process (Marschner, 1993; Rengel, 2015). As a consequence Zinc absorption through roots decreases which leads to less accumulation of Zinc in plants. This also results in reduced yield depending upon Zinc deficiency 
severity. In these conditions, application of Zinc fertilizer to soil/plant is a reliable approach ensuring appropriate uptake of Zinc in optimum concentration by roots (Cakmak et al., 1996; Rengel, 2015). Elevated pH level enables the Zinc to bind tightly to soil particle and cell wall which reduces Zinc acquisition and uptake by roots from rhizosphere. Moreover, additional factors like total sulphur content, bicarbonates and soil redox potential affects the Zinc uptake in anaerobic condition (Impa et al., 2012). Zinc deficiency causes severe impacts on human heath, especially in children, like impaired physical growth, weakened immune system and learning ability, and causing DNA damage and cancer development (Keenamp and Gershwin, 1990). The major role of Zinc in biological systems is, maintaining structural and functional integrity of biological membranes, protein synthesis and gene expression. Nearly half of the soils where cereals are grown have levels of available Zinc low enough to cause Zinc deficiency (Alloway, 2009).

\section{Importance of zinc in plants}

Zinc is one of the most essential nutrients required by all living organisms. It is the 23rd most abundant element (Broadley et al., 2007) and the 2nd most abundant transition metal (Jain et al., 2010). In plants zinc play an important role as it constituent or cofactor of many enzymes belonging to various classes like oxidoreductases, transferases, hydrolases, ligases, and isomerases (Auld 2001). These enzymes play important role in many biochemical pathways mainly concerened with metabolism of carbohydrates it include both photosynthesis and conversion to sucrose and starch also it work as cofactor of carbonic anhydrase which increases the carbon dioxide concentration of chloroplast, and thus also increases the carboxylation capability of the Rubisco enzyme (Salama et al., 2006) lipid metabolism, protein metabolism and nitrogen.
Zinc is involved in the biosynthesis of plant hormones like like auxin Abscisic acid, Gibberellin and Cytokinin, cytochrome, formation of pollen and maintaining integrality of cell membrane, synthesis of chlorophyll through the protection of the sulfydryl group, chloroplast development, some of their functions, such as the repair process of the photosystem II by 'recyclation 'of the D1 protein damaged by the light radiation or activity of the SPP peptidase and cell division (Sarwar et al., 2013; Sturikova et $a l ., 2018)$. It also plays a very important role in regulating ion balance in plant (Vazin 2012). Also, one of the other effects of $\mathrm{Zn}$ is in increasing in the levels of antioxidants in plant tissues as it works as cofactor of enzymes like such as superoxide dismutase, catalase. Zinc plays a fundamental role in protecting and maintaining structural stability of cell membranes (Cakmak, 2008, Cakmak, 2010). Zinc ions are also part of the transcription factor family, known as 'zinc fingers' that control the proliferation and differentiation of cells. It also regulates the functions of stomata by retaining potassium content of protective cells.

\section{Zinc in salinity mitigation}

Zinc plays an important in mitigating the adverse effect of salinity in plants. It is hypothesized that zinc mitigates salinity by (1) synthesis of auxin which in turn activate cell division and enlargement (2) maintain integrality of biomembranes (3) accumilation of phospholipids, (4) improvement in protein synthesis (5) scavenging free oxygen radicals (6) nutrient translocation from the aged cells to newborn cells (7) Decreasing the uptake of excess of $\mathrm{Na}^{+}$and $\mathrm{Cl}^{-}$(8) $\mathrm{K}$ and $\mathrm{Zn}$ play an important role in opening and closing the stomatal pore and controlling the process of photosynthesis. Therefore, high concentrations of $\mathrm{K}^{+}$in the stroma are required to maintain an optimum 
photosynthetic capacity under salinity stress conditions. Thus, maintaining the $\mathrm{Na}^{+} / \mathrm{K}^{+}$ ratio is the most important factor in salinity tolerance. Foliar application of zinc in wheat and mustard mitigate the harmful effects of salinity by restriction of sodium and chloride ions and absorption and compartmentation of important nutrients (Torabian et al., 2016; Fathi et al., 2016).

Leaf application of zinc under salinity decreased negative effects (plant biomass, water connections, gas exchange characteristics, and plant production in rice ((Ashraf et al., 2014). Vojodi Mehrabani et al., (2017) found that spraying zinc on Lavandula stoechas in saline condition alleviated the negative effects. Treatment of zinc helped rice plant to recover from the salinity depression by preventing $\mathrm{Na}^{+}$ion uptake, maintaining membranes integrity, better chlorophyll synthesis. Foliar spray of zinc increased accumulation of zinc, enhance $\mathrm{K}$ accumulation in plant tissue, reduce osmotic potential and increase turgor pressure in lavender plants under saline condition.

\section{Role of zinc in drought mitigation}

Zinc can affect the plant water relations as it alters the stomatal conductance and transpiration. The concentration of zinc effects the activity of zinc dependent enzyme like carbonic anhydrase, which regulates the $\mathrm{CO}_{2}$ sensing pathway and is related to drought tolerance (Tewari et al., 2019) and SOD and catalase involve in antioxidant defense pathway under drought stress (Yavas and Unay, 2016). Karim et al., (2012) found that zinc foliar application did not affect wheat grain yield under well watered condition, but increased grain yield and concentration of zinc in the grain under drought. Sultana et al., (2016) found that foliar $\mathrm{Zn}$ application counteracted the adverse effect of water deficit on wheat yield.

\section{Nanobiotechnology}

Nanobiotechnology is the new technology which involves the designing, characterization and application of material in nano size (100nm or less). This technology is widely used in the field of medicine, public health, trade and industry but its application in field of agriculture is at naïve stage and its use is increasing in this field as evicted by number of publication and patent granted (Kah et al., 2019). Nanoparticles increase growth and protect plants against a variety of abiotic stresses due to the small size, structural properties, and higher surface-tovolume ratio (Khan et al., 2014). In contrast other properties make them harmful leading to oxidative stress and cytotoxicity, and genotoxic responses. The degree of effectiveness or toxicity depends upon the chemical structure, size, surface area, reactivity and concentration used.

\section{Why zinc oxide nanoparticles?}

Zinc oxide nanoparticles have very small size enhancing the absorption, translocation, accumulation and assimilation in more dynamic way than the more common form of metal. $\mathrm{ZnO}$ nanoparticles are less toxic, comparatively inexpensive and biocompatible compared with other metal oxide nanoparticles because zinc does not interact with the majority of pharmaceutically active molecules (Sahdev et al., 2013). $\mathrm{ZnO}$ has been listed as a "generally recognized as safe (GRAS)" material by the Food and Drug Administration and is utilized as a food additive.

\section{Involvement of zinc oxide nanoparticles growth and development}

Shahhoseini et al., (2020) conducted as study to investigate the effects of zinc oxide nanoparticles (ZnONPs) on yield, metabolites 
content, and zinc and iron absorption of Feverfew. Nanoparticles at all concentrations increased the biological yield, essential oil content, and $\mathrm{Zn}$ absorption. Sadak and Bakry (2020) studied the effect of different concentration on nano $\mathrm{ZnO}(20,40$, and 60 $\mathrm{mg} / \mathrm{l})$ on various morpho-physiological parameters. Foliar application of $60 \mathrm{mg} / \mathrm{L}$ was found to be most effective for parameters like 1000 seeds wt. oil percentage; and seed, oil, biological, and straw yield/fed whereas concentration of $40 \mathrm{mg} / \mathrm{L}$ was effective for photosynthetic pigment content, shoot and root length, and shoots and root fresh and dry weight also zinc oxide in nano form significantly increased free amino acids, proline, and total carbohydrates of flax plants.

Bala et al., (2019) investigated the effect of different concentration of zinc oxide nanoparticles in Oryza sativa plants. Foliar application of 500 to $5000 \mathrm{ppm}$ increased growth and yield indices (height and shoot and root fresh and dry weights). Foliar application of zinc sulfate and zinc nanoparticles that positively affected the fresh weight of Coffea arabica (Rossi et al., 2019). Garcia-Lopez et al., (2019) found that 1000 ppm concentration of zinc oxide nanoparticles cause increase in height, stem diameter, chlorophyll, fruit yield, and total biomass and 2000 ppm increase in the total fruit, capsaicin content, dihydrocapsaicin, total phenols, total flavonoids (soluble + bound), and antioxidant capacity in fruits in habanero pepper plant. Seydmohammadi et al., (2019) used three concentrations of zinc oxide nanaoparticles (3, 6 and $9 \mathrm{mg} / \mathrm{L})$ to test the effect on the growth and flowering of lisianthus. It was found that foliar application of nano $\mathrm{ZnO}(6$ $\mathrm{mg} / \mathrm{L}$ ) increased number of leaf and lateral branches, leaf chlorophyll content and petal anthocyanin content and number of flowers.

Siddiqui (2018) found that application of $\mathrm{ZnO}$ NPs at $0.50 \mathrm{ml} / \mathrm{L}$ caused a greater increase in plant length, carotenoids, $\mathrm{H}_{2} \mathrm{O}_{2}$, chlorophyll, SOD, CAT, APX, PAL and proline contents and GSH contents followed by application of $\mathrm{ZnO}$ NPs with $0.25 \mathrm{ml} / \mathrm{L}^{-1}$. Xu et al., (2018) reported that the $\mathrm{ZnO} \mathrm{NPs}$, at $10 \mathrm{mg} / \mathrm{kg}$, enhanced the photosynthesis and biomass lettuce.

The possible reason for enhanced photosynthesis is due to an improvement in carbonic anhydrase, which could have facilitated the supply of $\mathrm{CO} 2$ to the sites of carboxylation in the chloroplast. Singh et al., (2018) reported that nano $\mathrm{ZnO}$ (at $50 \mathrm{ppm}$ ) was the best treatment for increasing rice seedling growth and improving physiological processes. López et al., (2018) found zinc oxide nanoparticle improved seed germination rate during the first seven days, seed vigor germination whereas zinc oxide nanoparticles did not affect plumule development, but they had a significant impact ( $\mathrm{p} 0.01$ ) on radicle length.

Rameshradd et al., (2017) investigated the impact of $\mathrm{Zn}$ Oxide $(\mathrm{ZnO})$ nanoparticles on $\mathrm{Zn}$ uptake, translocation and growth performance in rice in comparison to conventional $\mathrm{Zn}$ fertilizer $\left(\mathrm{ZnSO}_{4}\right)$. Seed priming with nano zinc showed improved plant height, chlorophyll content, biomass, tiller number and yield. The $\mathrm{Zn}$ content in leaf and seed is also higher in $\mathrm{ZnO}$ nano treated plant samples compared to $\mathrm{ZnSO}_{4}$ treatment. Mankad et al., (2017) assessed the effect of zinc oxide nanopaticles and their bulk counterpart rice and found out that nanoparticles treatments at lower concentration enhanced shoot and root length, fresh and dry weight, total chlorophyll and protein content along with seedlings antioxidant enzyme status superoxide dismutase, catalase and peroxidase. Tiwari et al., (2017) found in maize that zinc oxide nanopaticles at of 500 to $2000 \mathrm{ppm}$ of seed treatment and foliar treatment resulted in 
higher seed vigor, forage yield, grain yield, and higher zinc content. Mohsenzadeh and Moosavian (2017) reported the foliar application of zinc-sulfate and nano-zinc oxide positively affected the antioxidant enzymes activity as well as phenolics, proline, and chlorophyll content of rosemary (Rosmarinus officinalis L.).

Rameshraddy et al., (2017) showed that $\mathrm{ZnO}$ NPs (1000ppm) improve seed vigor of $45.54 \%$ with treatments of while at $1500 \mathrm{ppm}$ a significant reduction of this parameter was observed in seedling of ragi (finger millet). Venkatachalam et al., (2017) used zinc oxide nanoparticle of size $2-54 \mathrm{~nm}$ at different concentration of $25,50,75,100$, and 200 $\mathrm{mg} / \mathrm{L}$ and found that growth and photosynthetic pigment content increases with the increase in dose.

Upadhyaya et al., (2016) reported an exposure to $\mathrm{ZnO}$ nanopartcles at different concentration caused significant changes in radicle and plumule length, fresh, dry weight and seed moisture content in rice also antioxidant enzymes increased due to $\mathrm{ZnNP}$ treatment suggesting that $\mathrm{ZnO}$ nanoparticles may significantly alters antioxidant metabolism during rice seed germination. Singh et al., (2016) compared the effect of common $\mathrm{ZnSO}_{4}$ with $\mathrm{ZnO}$ nanoparticles on germination, seedlings viability, chlorophyll content, proteins, carbohydrates, and eventually the intensity of antioxidant activity (SOD) and lipid peroxidation (malondialdehyde) in tomatoes. Positive effect nano zinc oxide was on observed parameters of the plant at a lower concentration $(1.2 \mathrm{mM})$ in comparison with $\mathrm{ZnSO}_{4}$. Higher concentrations of nanoparticles $(6.1 \mathrm{mM})$. Amooaghaie et al., (2016) found that zinc oxide nanoparticles in concentration $(50 \mathrm{mg} / \mathrm{L})$ increased the root tolerance index (RTI) and seed germination tolerance index (GTI) in wheat. Adhikari et al., (2016) found that maize seeds coated with $\mathrm{ZnO}$ nanoparticles show better germination percentage (93-100\%) due to $\mathrm{ZnO}$ coating as compared to uncoated seeds (80\%). Subbaiah et al., (2016) reported ZnO NPs significantly influenced the growth, yield, and $\mathrm{Zn}$ content of maize grains. Zafar et al., (2016) found that application of ZnO-NPs to seeds of Brassica nigra, obtaining a negative effect in the root growth and resulted in an increase of $79 \%$ of DPPH radical scavenging activity and an increase in phenolic compounds was also obtained.

Farnia and Omidi (2015) reported positive increase in grain row per cob, number of grain per cob and grain yield of maize due to application of nano $\mathrm{Zn}$ fertilizer. Vafa et al., (2015) found growth parameters of savory plant; height, leaf number, leaves fresh and DW, chlorophyll, essential oil and phosphorus content were improved by nano-zinc application. Javadimoghadam et al., (2015) found concentrations of nanoparticles increased fresh and dry weights; in other words, the biological yield, relative to the control, indicates the positive effects of nanoparticles. Gokak and Taranath (2015) reported the improvement of characteristics associated to physiological quality of the seed may be attributed to NPs inducement of photosensitization reactions and photogeneration of active oxygen such as superoxide and hydroxide anions. These reactions stimulate the ion penetration and promote water and oxygen imbibition, necessary for rapid germination.

Ramesh et al., (2014) found that lower concentrations of $\mathrm{ZnO}$ NPs had beneficial effects on the seed germination of wheat. Mukherjee et al., (2014) while working on green peas exposed to different forms of zinc particles which includes bulk, nano and coated zinc particles found more tolerance in green pea plants treated with nano zinc. 
Rezaei and Abbasi (2014) reported that application of nano-chelate zinc improves physiological processes in cotton plant; increases chlorophyll content and antioxidant enzyme activity. Jayarambabu et al., (2014) studied the effect of $\mathrm{ZnO}$ nanoparticles on mungbean seeds (Vigna radiata L.) and revealed a significant improvement in germination, root length and shoot length at lower concentration. Laware and Raskar (2014) tested foliar application of zinc oxide nanopartcle growth parameters like plant height and number of leaves per plant were determined at the time of flowering and the seed yield contributing parameters like number of seeded fruits per umbel, seed yield per umbel and 1000 seed weight was determined at the time of harvest. Seed samples obtained from NP treated plants along with control were tested for germination and early seedling growth. The plants treated with $\mathrm{ZnO}$ NPs at the concentration of 20 and $30 \mu \mathrm{g} \mathrm{ml}^{-1}$ showed better growth and flowered 12-14 days earlier than the control. Treated plants showed significantly higher values for seeded fruit per umbel, seed weight per umbel and 1000 seed weight over control plants. Helaly et al., (2014) documented that adding nano- $\mathrm{ZnO}$ to MS medium enhances the activity of antioxidant enzymes in banana (Mousa sapientum), hence improving the abiotic stress tolerance.

Burman et al., (2013) also found maximum response with respect to shoot dry weight and overall biomass accumulation in chickpea treated with $1.5 \mathrm{ppm}$ of $\mathrm{ZnO}$ nanoparticles. Pokhrel and Dubey (2013) evaluated maize and cabbage seedlings against silver and zinc nanoparticles and reported similar increase in fresh weight at lower concentration. The enhancement in morphophysiological parameters may be attributed to accumulation of PGRs like cytokininins and gibberlins which plays an important role in cell division and elongation, respectively. De la Rosa et al., (2013) investigated the effect of $50-1600 \mathrm{mg} /$ $\mathrm{L} \mathrm{ZnO}$ NPs on cucumber, alfalfa, and tomato where it was extrapolated that seed germination was increased only in cucumber and the seed germination of tomato was reduced by merely $20 \%$ once were subjected to a concentration of $1600 \mathrm{mg} / \mathrm{L} \mathrm{ZnO} \mathrm{NPs}$. Raliya and Tarafdar (2013) reported that $\mathrm{ZnO}$ NPs significantly improved plant biomass, shoot and root growth, root area, chlorophyll content, and protein synthesis in cluster beans. El-Kereti and El-Feky, in turn, applied nanoparticles of $\mathrm{ZnO}$ (13 $\mathrm{nm}$ diameter) to the peanuts in the form of a spray, The treatment had a positive effect on several characteristics at once (total content of the chlorophyll, content of essential fatty acids, zinc content, plant height and fresh weight), which indicates the suitability of this treatment for improving the agricultural properties of peanuts.

Prasad et al., (2012) experiment was conducted that peanut seeds were separately treated with different concentrations of nano scale zinc oxide $(\mathrm{ZnO})$ and chelated bulk zinc sulfate $\left(\mathrm{ZnSO}_{4}\right)$ suspensions (a common zinc supplement), respectively and the effect this treatment had on seed germination, seedling vigor, plant growth, flowering, chlorophyll content, pod yield and root growth were studied Treatment of nano scale $\mathrm{ZnO}(25 \mathrm{~nm}$ mean particle size) at1000ppmconcentration promoted both seed germination seedling vigor and in turn showed early establishment in soil manifested by early flowering and higher leaf chlorophyll content. These particles proved effective in increasing stem and root growth. Pod yield per plant was $34 \%$ higher compared to chelated bulk $\mathrm{ZnSO}_{4}$.

Mahajan et al., (2011) found that ZnO NPs promoted the root, shoot length, root and shoot biomass of Vigna radiata and Cicer arietinum. Boonyanitipong et al., (2011) indicated that application of $\mathrm{ZnO}$ 
nanoparticles at concentration $10 \mathrm{mg} / \mathrm{L}$ led to $100 \%$ germination of rice seeds and little increase in root length and number of roots.

Pandey et al., (2010) observed a positive response with $\mathrm{ZnO}$ NPs on seed germination and root growth of Cicer arietinum. $\mathrm{ZnO}$ nanoparticles affect the reactivity of phytohormones, especially indole acetic acid (IAA) which involved in the phytostimulatory actions.

\section{Zinc oxide nanoparticles in salinity mitigation}

Noohpisheh et al., (2020) studied the effects of zinc oxide $(\mathrm{ZnO})$ nanoparticles under salinity stress in two cultivars of Trigonella foenum-graecum and reported that the effects are cultivar and salinity dependent. Nanoparticle increased the concentration of calcium of root in one cultivar where it decreased in other. In addition zinc oxide nanopartice increased proline content and trigonelline content under salinity and normal condition.

Wang et al., (2019) used zinc oxide nanoparticles $\left(50 \mathrm{mg} \mathrm{L}^{-1}\right)$ for wheat seed priming and after 20 days recovery of priming the plants were exposed to salt stress of (200 $\mathrm{mM} \mathrm{NaCl}$ ) for 10 days. Priming of zinc oxide nanoparticles reduced the concentration of sodium and increased water.

The nanoparticles were effective in scavenging reactive oxygen species as exemplified by enhanced activity of various activities of antioxidant enzymes like SOD, APX and CAT leading to better homeostasis of ROS production. Priming also increased activities of phosphoglucomutase and cytoplasmic invertase which promoted the sucrose biosynthesis higher shoot dry weight, leaf proline concentration.
In addition photosynthetic rate was decreased by the nano- $\mathrm{ZnO}$ priming in wheat plants under normal condition. However, when exposed to salt stress, the nano- $\mathrm{ZnO}$ primed plants had significantly higher photosynthetic rate than the non-primed plants. Also, higher stomatal conductance and transpiration rate were found in nano- $\mathrm{ZnO}$ primed plants, compared with the non-primed plants. Hassanpouraghdam et al., (2019) evaluated the role of nano zinc foliar application with two concentrations ( 0 and $3 \mathrm{mg} \mathrm{L}^{-1}$ ) for salinity mitigation of $\mathrm{NaCl}$ salinity $(0,75$, 150, and $225 \mathrm{mM}$ ) in plant Rosmarinus officinalis.

Foliar application showed positive effects on plant fresh weight, total flavonoids and zinc content under control condition without salinity. Nano zinc doubled the content of chlorophyll a and as a consequence total chlorophyll in non-saline $(0 \mathrm{mM}$ of $\mathrm{NaCl})$ and saline-treated $(\leq 150 \mathrm{mMof} \mathrm{NaCl})$ plants. Whereas these nanopaticles showed negative effect on concentration of chlorophyll b. Foliar application also decreased $\mathrm{H} 2 \mathrm{O} 2$ (up to $22 \%$ ) and MDA (up to $26.9 \%$ ) content in plants grown at $\geq 150 \mathrm{mM} \mathrm{NaCl}$ and at 225 $\mathrm{mM} \mathrm{NaCl}$.

Vojodi Mehrabani et al., (2018) used nano zinc and common form source of zinc under salt stress to study their effects on morphological and physiological traits of Rosmarinus officinalis. These nanopartcles showed show effect on elemental content $\left(\mathrm{K}^{+}\right.$, $\mathrm{Na}^{+}$and $\mathrm{Zn}^{2+}$ ), as well as essential oil yield of the plants, also soluble sugars content, flavonoids, $\mathrm{H}_{2} \mathrm{O}_{2}$ and MDA contents were influenced by individual levels of salinity and zinc foliar applications. It was concluded that nano-zinc foliar spray was able to overcome the mild salinity effects on the plant growth and physiological parameters. Hussein and Baker (2018) found that the foliar application of nano-Zinc (200 ppm) led to mitigating the 
adverse effect of salinity and confirmed that diluted seawater could be used in the irrigation of cotton plant.

Latef et al., (2017) to evaluate the effect of $\mathrm{ZnO}$ nanoparticles $(20,40$ and $60 \mathrm{mg} / \mathrm{l})$ on lupine plants (Lupinus termis) subjected salinity $(150 \mathrm{mM} \mathrm{NaCl})$. Treatment with $\mathrm{ZnO}$ nanoparticles (especially in $60 \mathrm{mg} / \mathrm{l}$ concentration) in plants stressed by salinity stimulated growth, promoted the formation of photosynthetic pigments, phenolic compounds, ascorbic acid and increased the activity of superoxide dismutase, catalase and other antioxidant enzymes.

Vojodi Mehrabani et al., (2017) reported that $\mathrm{Zn}$ spraying in saline-treated Lavandula stoechas alleviated the negative effects (decreased dry weight) of salinity. Babaei $e t$ al.(2017) reported positive effects of zinc oxide naopaticles on biomass production and yield of wheat under salinity stress. Tawfik $e t$ al., (2017) stated that nano $\mathrm{Zn}$ increased growth parameters of Atriplex halimus.

Torabian et al., (2016) studied the effects of normal and nanoparticles of zinc oxide ( $\mathrm{ZnO})$ foliar application on the growth, proline content, and some antioxidant enzyme activities of sunflower cultivars at different salinity levels and reported higher shoot dry weight of sunflower in $\mathrm{ZnO}$ nanoparticles treatment compared to normal form which could be due to reason that mobility of the nanoparticles is very high, which leads to rapid transport of the nutrient to all parts of the plant. Due to its small size, the availability of the nanoparticle of $\mathrm{ZnO}$ can be higher compared to the normal form.

Alharby et al., (2016) reported that ZnO NPs alter mRNA expression of SOD and GPX genes, and proteins in tomato (Lycopersicon esculentum Mill.) plant subjected to $\mathrm{NaCl}$ stress.
Taheri et al., (2015) the nano- $\mathrm{ZnO}$ primed wheat plants had higher Fv/Fm than the nonprimed plants under salt stress. This illuminated that the quantum yield of the PSII of wheat leaves under salt stress is enhanced by the nano- $\mathrm{ZnO}$ priming. The under salt stress. The $\mathrm{ZnO}$ NPs increase shoot dry matter and leaf area indexes. The effect of application of Hoagland solution containing $\mathrm{ZnO}$ and $\mathrm{Fe} 2 \mathrm{O} 3$ nanoparticles in Moringa peregrine under salinity stress. The application of nanoparticles lower $\mathrm{Na}$ and $\mathrm{Cl}$ and higher $\mathrm{N}, \mathrm{K}, \mathrm{Ca}, \mathrm{Mn}, \mathrm{Zn}$, and Fe. Lower $\mathrm{Na}$ storage is considered as an important indicator for salinity tolerance (Soliman et al., 2015).

\section{Zinc oxide nanoparticles in drought mitigation}

Dhalim and Ajeel (2020) evaluate the effect of foliar application of different zinc source including zinc sulphate, zinc oxide and nano zinc at concentration of $100 \mathrm{ppm}$ in sunflower (Helianthus annuиs 1.) under different irrigation time and found highest level of auxine (IAA), Gibberline (GA3) in plants treated with the Nano-zinc treatment at concentration of $100 \mathrm{ppm}$ and treatment of 3 days interval irrigation. Plants irrigated every 9 days and treated with nano zinc oxide had the highest ABA compared to other treatment combinations. Nano-zinc application increased leaf content of zinc more than application of normal zinc. The highest values for leaf content of zinc (15.64 and 13.32 $\mathrm{mg} / \mathrm{g}^{-1}$ ) were recorded in the 3 days intervals. Upadhyaya et al., (2020) studied the effect of zinc oxide nanoparticles for drought mitigation in rice. He reported that under drought stress there was decrease in root and shoot length the changes were comparatively lesser in $\mathrm{ZnO}$ treated plant and its interaction with 5 and 10\% PEG treatment. Dry mass of shoot decreased due to water stress but it increased under $\mathrm{ZnO} \mathrm{NP}$ and water stress in 
presence of $\mathrm{ZnO} \mathrm{NP}$ treatment. The nanoparticle treatement did not show any significant difference in relative water content. Zinc content in both roots and shoot plant subjected to $\mathrm{ZnO} \mathrm{NP}$ and its interaction with water stress increased. The activity of antioxidant enzymes CAT and POX increased mainly in shoot due to $\mathrm{ZnO} \mathrm{NP}$ in both control and stressed plants but water stress resulted decreased in CAT activities. Sun et al., (2020) investigated the effect of nano zinc at the concentration of $\left(100 \mathrm{mg} \mathrm{L}^{-1}\right)$ in maize under drought stressed and well-watered maize.

The effect was studied on stomatal morphology, gas exchange and key carbon metabolism enzyme activities. It was found that the application of nanoparticle alleviated photosynthetic pigment degradation and benefited the stomatal movement, maintained a higher net photosynthetic rate, and enhanced water use efficiency, promoting the drought tolerance in maize also it increased the activity of UDP-glucose pyrophosphorylase, phosphoglucoisomerase and cytoplasmic invertase by $17.8 \%, 391.5 \%$ and $126 \%$ respectively, which enhanced the starch and sucrose biosynthesis and glycolysis metabolism in leaves under drought stress and concluded that these nanoparticles have potential to alleviate ill effect of salinity.

Dimkpa et al., (2019) evaluated harmful effects of drought in sorghum and whether $\mathrm{ZnO}$ nanoparticles ( $\mathrm{ZnO}-\mathrm{NPs}$ ) might alleviate such effects. It was found that under drought flag leaf emergence and heading were were delayed 6-17 days but application of zinc oxide nanoparticles reduced the delay by 45 days. Drought significantly $(\mathrm{p}<0.05)$ reduced $(76 \%)$ grain yield; however, $\mathrm{ZnO}-\mathrm{NP}$ amendment under drought improved grain (22-183\%) yield. Drought lowered (32\%) average grain $\mathrm{Zn}$ concentration; however, $\mathrm{ZnO}-\mathrm{NP}$ amendments improved (94\%) grain
Zn under drought.

Taran et al., (2017) showed that Znnanoparticles decreased the negative effect of drought action on wheat seedling by increasing the activity of antioxidative enzymes reduced the level of accumulation of thiobarbituric acid reactive substances (TBARS) and stabilized the content of photosynthetic pigments and increased relative water content in leaves. Pavithra et al., (2017) reported plants treated with $\mathrm{ZnO}$ NPs $(1000 \mathrm{mg} / \mathrm{L})$ show improved plant height, chlorophyll content, biomass, tiller number, and yield. It improves drought tolerance of rice plant by maintaining the membrane stability and higher expression of $\mathrm{Cu} / \mathrm{Zn}$ SOD. Yang et al., (2017) reported zinc oxide nanoparticles induce remodeling of root morphology by increasing lateral root formation in wheat under drought stress. Sedghi et al., 2013 studied the effects of different concentration of zinc oxide nanoparticles $\left(0,0.5,1 \mathrm{~g} / \mathrm{lit}^{-1}\right)$ on drought stress imposed by poly ethyl glycol and found that zinc oxide nanoparticles at low concentration increase germination rate and germination percentage, root length, root fresh and dry weight, seed residual fresh and dry weight.

In conclusion, modern age nanotechnology is fast growing technology and nanoparticles are used intensively and becoming a part of the human life. However, the applications on nanotechnology and use of nanoparticles in sustainable agriculture and crop improvement are still at juvenile phase. Therefore, in order to harness the peculiar and unique properties of NPs in agriculture sector to get maximum potential advantages, it has become necessary to build up basic understanding regarding interaction of NPs with plants at cellular as well as molecular level. Zinc oxide nanoparticles have very small size enhancing the absorption, translocation, accumulation and assimilation in more dynamic way than 
the more common form of metal. $\mathrm{ZnO}$ nanoparticles are less toxic, comparatively inexpensive and biocompatible compared with other metal oxide nanoparticles. $\mathrm{ZnO}$ has been listed as a "generally recognized as safe (GRAS)" material by the Food and Drug Administration and is utilized as a food additive thus zinc oxide nanoparticles can be used for mitigation of different abiotic stress.

\section{References}

Abdel Latef, Arafat. (2017). The Possible Roles of Priming with $\mathrm{ZnO}$ Nanoparticles in Mitigation of Salinity Stress in Lupine (Lupinus termis) Plants. Journal of Plant Growth Regulation. 36, 60-70.

Adhikari, T., Sarkar, D., Mashayekhi, H., Xing, B. (2016) Growth and enzymatic activity of maize (Zea mays L.) plant: solution culture test for copper dioxide nano particles. Journal of Plant Nutrition, 39(1), 99-115.

Alloway, B.J. (2009). Soil factors associated with Zinc deficiency in crops and humans. Environmental Geochemistry and Health, 31, 537-548.

Amooaghaie, R. Norouzi, M. and Saeri, M.R. (2016). Impact of zinc and zinc oxide nanoparticles on the physiological and biochemical processes in tomato and wheat. Botany, 95. 10.1139/cjb-20160194.

Alharby, H.F., Metwali,E.M.R., Fuller,M.P. and Aldhebiani, A.Y.(2016) The alteration of mRNA expression of SOD and GPX genes, and proteins in tomato (Lycopersicon esculentum mill) under stress of $\mathrm{NaCl}$ and/or $\mathrm{ZnO}$ nanoparticles, Saudian Journal of Biological Science, 23 ,773-781.

Ashraf, M. (2001) Relationships between growth and gas exchange characteristics in some salt-tolerant amphidiploid Brassica species in relation to their diploid parents. Environment Experiment Botany, 45, 155-163.

Auld, D. S. (2001) Zinc coordination sphere in biochemical zinc sites. Biometals, 14, 271313.

Bala,R., Kalia,A. and Dhaliwal, S.S (2018) Evaluation of Efficacy of $\mathrm{ZnO}$ Nanoparticles as Remedial Zinc Nanofertilizer for Rice. Journal of Soil Science and Plant Nutrition. DOI: 10.1007/s42729-019-00040-z

Boonyanitipong, P., Kositsup, B., Kumar, P., Baruah, S.and Dutta, J. (2011) Toxicity of $\mathrm{ZnO}$ and $\mathrm{TiO} 2$ nanoparticles on germinating rice seed Oryza sativa L. International Journal of Bioscience, Biochemistry and Bioinformatics, 1, 282-285.

Broadley, M.R., White, P.J., Hammond, J.P., Zelko, I. and Lu, A. (2007) Zinc in plants. New Phytology, 173, 677-702.

Burman, U., Saini, M. and Kumar, P. (2013) Effect of zinc oxide nanoparticles on growth and antioxidant system of chickpea seedlings. Toxicology Environmental Chemistry, 95, 605-612.

Cakmak, I. (2000) Tansley Review No. 111: possible roles of Zinc in protecting plant cells from damage by reactive oxygen species. New Phytologist, 146(2), 185205.

Cakmak, I., Pfeiffer, W. H. and McClafferty, B. (2010) Biofortification of durum wheat with Zinc and Iron. Cereal chemistry, 87(1), 10-20.

Cakmak, I., Yilmaz, A., Kalayci, M., Ekiz, H., Torun, B., Ereno, B. and Braun, H. J. (1996) Zinc deficiency as a critical problem in wheat production in Central Anatolia. Plant and soil, 180(2), 165172.

Dhalimi,A.M. and Ajeel, S.A.H (2020) Effect Of Plant Regulators, Zinc Nanoparticles And Irrigation Intervals On Leaf Content Of Endogenous Hormones And Nutrients In Sunflower (Helianthus Annuus L.). Plant Archives, 20, 27202725.

Dimkpa, C. O., Singh, U., Bindraban, P. S., Elmer, W. H., Gardea-Torresdey, J. L. and White, J. C.(2019) Zinc oxide nanoparticles alleviate drought-induced 
alterations in sorghum performance, nutrient acquisition, and grain fortification. Science Total Environment ,688, 926-934.

El-Kereti, M.A., El-Feky, S.A., Khater, M.S., Osman, Y.A. and El-Sherbini, E.S.A. (2013) $\mathrm{ZnO}$ nanofertilizer and $\mathrm{He} \mathrm{Ne}$ laser irradiation for promoting growth and yield of sweet basil plant. Recent Patent on Food Nutrition and Agriculture, 5, 169-181.

Farnia, A., Omidi, M.M. and Farnia, A. (2015) Effect of nano-zinc chelate and nanobiofertilizer on yield and yield components of maize (Zea mays L.) under water stress condition. Indian Journal of Natural Science, 5, 46144646.

Fathi,M., Haydari,M. (2016) . Effects of zinc oxide nanoparticles on antioxidant status, serum enzymes activities, biochemical parameters and performance in broiler chickens. Journal of Livestock Science and Technologies, 4,7-13.

Garcia-Lópes, J., Nino-Medina, G., OlivaresSàenz, E., Lira- Saldivar, R., BarrigaCostro, E., Vàzques-Alvarado, R., Rodriguez-Salinas, P. and ZavalaGarcia, F. (2019). Foliar application of zinc sulfate boosts the content of bioactive compound in Habanero peppers. Plants, $8(254), 1-20$

Gokak, I. B. and Taranath, T. C. (2015) Seed germination and growth responses of Macrotyloma uniflorum (Lam.) Verdc. exposed to Zinc and Zinc nanoparticles. International journal of environment science, 5(4), 840-847.

Hassanpouraghdam, M.B., Mehrabani, L.V. and Tzortzakis, N. (2019) Foliar Application of Nano-zinc and Iron Affects Physiological Attributes of Rosmarinus officinalis and Quietens $\mathrm{NaCl}$ Salinity Depression. Journal of Soil Science and Plant Nutrition, 20, 335-345.

Helaly, M.N., El-Metwally, M.A., El-Hoseiny, H., Omar, S.A. and El-Sheery, N.I. (2014) Effect of nanoparticles on biological contamination of in vitro cultures and organogenic regeneration of banana. Australian Journal of Crop Science, 8, 612-624

Hussein, M.M. (2018) The contribution of nano-zinc to alleviate salinity stress on cotton plants. Royal Society Open Science, 5, 171809.

Impa, S. M., and Johnson-Beebout, S. E. (2012) Mitigating Zinc deficiency and achieving high grain $\mathrm{Zn}$ in rice through integration of soil chemistry and plant physiology research. Plant and Soil, 361(1-2), 3-41.

Jain, R., Srivastava, S., Solomon, S., Shrivastava, A.K. and Chandra, A. (2010) Impact of excess zinc on growth parameters, cell division, nutrient accumulation, photosynthetic pigments and oxidative stress of sugarcane (Saccharum spp.). Acta Physiol Plant, 32,979

Javadimoghadam, A., Moghadam, A.L. and Danaee, E. (2015) Response of growth and yield of cucumber plants (Cucumis sativus L.) to different foliar applications of nano- iron and zinc. International Research Journal of Applied and Basic Sciences,9(9), 14771478.

Jayarambabu, N., Sivakumari, B. and Prabhu, Y.T. (2014) Germination and growth characteristics of mungbean seeds affected by synthesized zinc oxide nanoparticles. International Journal of Current Engineering and Technology, 5, 3411-3416.

Kah, M., Tufenkji, N. and White, J.C. (2019) and protection. Nature Nanotechnology, 14,522- 540.

Keen, C. L. and Gershwin, M. E. (1990) Zinc deficiency and immune function. Annual review of nutrition, 10, 415-431.

Karim, M.D., Zhang, Y., Zhao, R.R., Chen, X.P., Zhang, F.S. and Zou, C. (2012) Alleviation of drought stress in winter wheat by late foliar application of zinc, boron, and manganese. Journal of Plant Nutrition and Soil Science, 
175,10.1002/jpln.201100141.

Khan, M.R. and Rizvi, T.F. (2014) Nanotechnology: Scope and application in plant disease management. Journal of plant pathology, 13, 214-231.

Laware, S.L. and Raskar, S. (2014) Original Research Article Influence of Zinc Oxide Nanoparticles on Growth, Flowering and Seed Productivity in Onion. International journal of current microbiology and applied science, 3, 874-881.

López-moreno, M.L., De, G., Cruz-jiménez, G., Castellano, L., Peralta-videa, J.R. and Gardea-torresdey, J.L. (2017) Effect of $\mathrm{ZnO}$ nanoparticles on corn seedlings at different temperatures; X-ray absorption spectroscopy and ICP / OES studies. Microchemical Journal, 134, 54-61.

Lu,Y.,Latha,P., Munaswamy, V., Reddy, K. Sreeprasad, T.S., Sajanlal, P.R.and Pradeep, T. (2012) Effect of nanoscale zinc oxide particles on the germination, growth and yield of peanut. International Journal of Plant Nutrition, 35(6), 905-927.

Mahajan P, Dhoke, S.K. and Khanna, A.S. (2011) Effect of nano-ZnO particle suspension on growth of mung (Vigna radiata)and gram (Cicer arietinum) seedlings using plant agar method. Journal of Nanotechnology, https://doi.org/10.1155/2011/696535

Mankad, M., Patil, G., Patel, S., Patel, D. and Patel, A. (2016) Green synthesis of zinc oxide nanoparticles using Azadirachta indica A. Juss. leaves extract and its antibacterial activity against Xanthomonas orzyae pv. Oryzae. Annals of Phytomedicine, 5(2), 76-86

Marschner, H. (1993) Zinc uptake from soils. Zinc in soils and plants, 9, 59-77.

Mohsenzadeh, S. and Moosavian, S.S. (2017) Zinc sulphate and nano-zinc oxide effects on some physiological parameters of Rosmarinus officinalis. American Journal of Plant Sciences, 8, 2635-2649.
Mukherjee, A., Pokhrel, S., Bandyopadhyay, S., Madler, L., Peralta-Videa, J.R. and Torresdey, J.L.G. (2014) A soil mediated phyto-toxicological study of iron doped zinc oxide nanoparticles (Fe and $\mathrm{ZnO}$ ) in green peas (Pisum sativum L.). Chemical Engineering Journal, 258,394-401.

Noohpisheh, Z., Amiri, H., Mohammadi,A. and Farhadi, S. (2020) Effect of the Foliar Application of Zinc Oxide Nanoparticles on Some Biochemical and Physiological Parameters of Trigonella foenumgraecum under Salinity Stress. Plant Biosystems - An International Journal, DOI: 10.1080/11263504.2020.1739160

Pandey, A. C., Sanjay, S. S. and Yadav, R. S. (2010) Application of $\mathrm{ZnO}$ Nanoparticles in Influencing the Growth Rate of Cicer arietinum. Journal of Experimental Nanoscience, 5, 488-497.

Pavithra, G.J., Reddy, B.R., Salimath, M., Geetha, K.N. and Shankar, A.G. (2017) Zinc oxide nano particles increases $\mathrm{Zn}$ uptake, translocation in rice with positive effect on growth, yield and moisture stress tolerance. Indian Journal of Plant Physiology, 22 (3), 287-294.

Pokhrel, L.R. and Dubey, B. (2013) Evaluation of developmental responses of two crop plants exposed to silver and zinc oxide nanoparticles. Science of the Total Environment, 452, 321-332.

Raliya, R. and Tarafdar, J.C. (2013) ZnO nanoparticle biosynthesis and its effect on phosphorous mobilizing enzyme secretion and gum contents in clusterbean (Cyamopsis tetragonoloba L.). Agriculture Research, 2, 48-57.

Ramesh, M., Palanisamy, K., Babu, K., Sharma, N.K. (2014) Effects of bulk \& nanotitanium dioxide and zinc oxide on physio-morphological changes in (Triticum aestivum Linn). Journal of Global Biosciences, 3 (6), 415-422.

Rameshraddy, Pavithra, G.J., Rajashekar Reddy, B.H., Mahesh, S., Geetha, K.N. 
and Shankar, A.G.(2017) Zinc oxide nano particles increases $\mathrm{Zn}$ uptake, translocation in rice with positive effect on growth, yield and moisture stress tolerance. Indian Journal of Plant Physiology, 22, 287-294.

Rengel, Z. (2015) Availability of Mn, Zn and $\mathrm{Fe}$ in the rhizosphere. Journal of soil science and plant nutrition, 15(2), 397 409.

Rezaei, M. and Abbasi, H. (2014) Foliar application of nanochelate and nonnanochelate of zinc on plant resistance physiological processes in cotton (Gossipium hirsutum L.). Iran Journal of Plant Physiology, 4, 1137-1144.

Rosa, G.D., Lopez-Moreno, M.L., Haro, D.D., Botez, C.E., Peralta-Videa, J.R., Gardea and Torresdey, J.L.(2013) Effects of $\mathrm{ZnO}$ nanoparticles in alfalfa, tomato, and cucumberat the germination stage: root development and X-ray absorption spectroscopy studies. Pure Applied Chemistry, 85, 2161-2174.

Rossi, L., Fedenia, L.N., Sharifan, H., Ma, X. and Lombardini, L.J.P (2019) Biochemistry: Effects of foliar application of zinc sulfate and zinc nanoparticles in coffee (Coffea arabica L.). Plants, 135, 160-166.

Sadak, M.S. (2020) Zinc-oxide and nano $\mathrm{ZnO}$ oxide effects on growth, some biochemical aspects, yield quantity, and quality of flax (Linum uitatissimum L . ) in absence and presence of compost under sandy soil. Bulletin of the National Research Centre , 2, 44-98.

Sahdev, P., Podaralla, S., Kaushik, R.S. and Perumal, O. (2013) Calcium phosphate nanoparticles for transcutaneous vaccine delivery. Journal of Biomedical Nanotechnology, 9, 132-141.

Salama, Z., Fouly, M.M., Lazova, G. and Popova (2006) Carboxylating enzymes and carbonic anhydrase functions were suppressed by zinc deficiency in maize and chickpea plants. Acta Physiologiae Plantarum, 28,445-451.

Sarwar, M.H., Sarwar, M.F., Sarwar, M, Qadri,
N.A. and Moghal, S. (2013) The importance of cereals (Poaceae: Gramineae) nutrition in human health: A review. Journal of Cereals and Oilseeds, 4(3), 32-35.

Sedghi, M., Hadi, M. and Toluie, S.G. (2013) Effect of nano zinc oxide on the germination of soybean seeds under drought stress. Annals of West University of Timisoara: Series of Biology, 16, 73-78.

Seydmohammadi, Z., Roein, Z. and Rezvanipour, S. (2019) Accelerating the growth and flowering of Eustoma grandiflorum by foliar application of nano-ZnO and nano-CaCO 3. Plant Physiology Reports, 74, 114-119.

Shahhoseini, R., Azizi, M., Asili, J., Moshtaghi, N. and Samiei, L. (2020) Effects of zinc oxide nanoelicitors on yield, secondary metabolites, zinc and iron absorption of Feverfew (Tanacetum parthenium ( L .) Schultz Bip.). Acta Physiologiae Plantarum, 17, 1-18.

Siddiqui, Z.A., Khan, M.R., Abdallah, E.F. and Parveen, A. (2018) Titanium dioxide and zinc oxide nanoparticles affect some bacterial diseases, and growth and physiological changes of beetroot. International Journal of Vegetable Science, 00, 1-22.

Singh, A., Singh, N.B., Afzal, S., Singh, T. and Hussain, I. (2018). Zinc oxide nanoparticles: a review of their biological synthesis, antimicrobial activity, uptake, translocation and biotransformation in plants. Journal of Material Science, 53, 185-201.

Singh, S., Tripathi, D.K., Dubey, N.K. and Chauhan, D.K. (2016) Effects of nanomaterials on seed germination and seedling growth: striking the slight balance between the concepts and controversies. Material Focus, 5 (3), 195-201.

Soliman, A.S, El-feky, S.A and Darwish, E. (2015) Alleviation of salt stress on Moringa peregrine using foliar application of nanofertilizers. Journal of 
Horticulture and Forestry, 7, 36-47.

Sturikova, H., Krystofova, O., Huska, D. and Adam, V. (2010) Zinc, zinc nanoparticles and plants, Journal of Hazardous Materials (2010), https://doi.org/10.1016/j.jhazmat.2018.0 1.040

Subbaiah, L.K., Vara Prasad, T.N.V.K., Krishna., T.G., Sudhakar, P., Reddy, B.R., Thalappil, P. (2018) Novel Effects of Nanoparticulate Delivery of Zinc on Growth, Productivity, and Zinc Biofortification in Maize (Zea mays L.). Journal of Agricultural and Food Chemistry.

DOI:

10.1021/acs.jafc.6b00838.

Sultana, S., Naser, Habib, Shil, N.C., Akhter, Shireen and Begum, R.A. (2016) Effect of foliar application of zinc on yield of wheat grown by avoiding irrigation at different growth stages. Bangladesh Journal of Agricultural Research, 41, 323. 10.3329/bjar.v41i2.28234.

Sun,L., Song,F., Zhu,X., Liu., Liu.F., Wang,Y. and Li.,Z (2020) Nano-ZnO alleviates drought stress via modulating the plant water use and carbohydrate metabolism in maize. Archives of Agronomy and Soil Science, DOI: 10.1080/03650340.2020.1723003

Taheri, M., H.A., Qarache, A.A., Qarache, A. and Yoosefi, M. (2015) The effects of zinc-oxide nanoparticles on growth parameters of corn (SC704). STEM Fellowship Journal, 1(2),17-20. doi: 10.17975/sfj-2015-011.

Taran, N., Storozhenko, V., Svietlova, N., Batsmanova, L., Shvartau, V., Kovalenko, M. (2017) Effect of zinc and copper nanoparticles on drought resistance of wheat seedlings. Nanoscale Research Letter, 12, 60. https://doi.org/ 10.1186/s11671-017-1839-9.

Tawfik, M.M., Bakhoum, G.S., Sadak, Mervat, S. and Kabesh, M.O. (2017) Application of $\mathrm{ZnO}$ nanoparticles for sustainable production of Atriplex halimus in saline habitats. Bull NRC ,41(Bi.2),286-305

Tiwari, P.K. (2017) Effect of zinc oxide nanoparticles on germination, growth and yield of maize (Zea mays L.). M.Sc. Thesis, Anand Agriculture university, India.

Tewari, R., Kumar, P. and Sharma, P.N. (2019) An effective antioxidant defense provides protection against zinc deficiency-induced oxidative stress in Zn-efficient maize plants. Journal of plant nutrition and soil science,182, 701-707.

Torabian, S., Zahedi, M. and Khoshgoftarmanesh, A. (2016) Effects of foliar spray of zinc oxide on some antioxidant enzymes activity of sunflower under salt stress. Journal of Agriculture Science Technology, 18(4), 1013-1025

Upadhyaya, H., Roy, H., Shome, S., Tewari, S. and Mk, B. (2017) Physiological impact of Zinc nanoparticle on germination of rice (Oryza sativa L) seed. Journal of Plant Science and Phytopathology , 6270.

Upadhyaya, H., Shome,S., Tewari,S., Bhattacharya., M.K. and Panda, S.K (2020) Responses to ZnO Nanoparticles During Water Stress in Oryza sativa L. Journal of Stress Physiology \& Biochemistry, 16(2), 67-74.

Vafa, Z.N., Sirousmehr, A.R., Ghanbari, A., Khammari, E and Falahi, N. (2015) Effect of nano-zinc and humic acid in quantitative and qualitative characteristics of savory (Satureja hortensis L.) International journal of BioScience, 6, 124-136.

Vazin, F. (2012) Effect of zinc sulfate on quantitative and qualitative characteristics of corn (zea mays) in drought stress. Cercetări Agronomice în Moldova, 16 (3),(151).

Venkatachalam, P., Jayaraj, M., Manikandan, R., Geetha, N., Rene, E.R., Sharma, N.C. and Sahi, S.V.( 2017). Zinc oxide nanoparticles (ZnONPs) alleviate heavy metal-induced toxicity in Leucaena leucocephala seedlings: A physiochemical analysis. Plant 
Physiology and Biochemistry,110, 5969.

Vojodi Mehrabani, L., Hassanpouraghdam, M.B. and Shamsi-Khotab, T. (2018) The effects of common and nano-zinc foliar application on the alleviation of salinity stress in Rosmarinus officinalis L. Acta Scientiarum Polonorum Hortorum Cultus, 17(6),65-73

Vojodi Mehrabani, L, Kamran, R.V., Hassanpouraghdam, M.B and Pessarakli, M. (2017) Zinc sulfate foliar application effects on some physiological characteristics and phenolic and essential oil contents of Lavandula stoechas L. under sodium chloride $(\mathrm{NaCl})$ salinity conditions. Communications in Soil Science and Plant Analysis, 48(16), 1860-1867.

Wang, Z., Li, H., Li, X., Xin, C., Si, J., Li, S.,
Li, Y., Zheng, X., Li, H., Wei, X., Zhang, Z., Kong, L. and Wang, F. (2020) Nano-ZnO priming induces salt tolerance by promoting photosynthetic carbon assimilation in wheat. Archives of Agronomy and Soil Science, 10.1080/03650340.2019.1663508.

Yash, I. and Unay, A. (2016) Effects of zinc and salicylic acid on wheat under drought stress. The Journal of Animal \& Plant Sciences, 26(4), 1012-1018.

Zafar,H., Ali,A., Joham, S., Haq, I.U. and Muhammad, Z. (2016) Effect of ZnO Nanoparticles on Brassica nigra Seedlings and Stem Explants: Growth Dynamics and Antioxidative Response . Frontiers in Plant Science. 7:535. doi: 10.3389/fpls.2016.00535.

\section{How to cite this article:}

Pooja, Renu Munjal, Jayeeta Bhaumik and Ravneet Kaur. 2020. Role of Zinc Oxide Nanoparticles in Mitigation of Drought and Salinity-A Review. Int.J.Curr.Microbiol.App.Sci. 9(11): 467-481. doi: https://doi.org/10.20546/ijcmas.2020.911.058 